\title{
ЭКОНОМИЧЕСКАЯ ИНТЕГРАЦИЯ ЕАЭС СО СТРАНАМИ, НЕ ВХОДЯЩИМИ В ЭКОНОМИЧЕСКИЙ СОЮЗ
}

\author{
(C) 2020 Бурцева К.Ю. \\ кандидат экономических наук, доцент Департамента бизнес-аналитики \\ Финансовый университет при Правительстве Российской Федерации, Россия, Москва \\ E-mail: aksentiya@mail.ru
}

ЕАЭС развивает и наращивает связи со странами, не являющимися членами союза. В статье проведен анализ возможностей будущего партнёрства с ЕАЭС. Стратегии выстраивания взаимоотношений основаны на заключении соглашений о ЗСТ, снижении таможенных пошлин, наращивании товарооборота с союзом, заключении экономических соглашений. Сделан вывод о том, что торговые отношения ЕАЭС и стран, не входящих в союз, достаточно выгодны как для России, так и других стран-участниц ЕАЭС.

Ключевые слова: ЕАЭС, экономика, интеграция, соглашение, экспорт, импорт, рынок, товарооборот, экономические отношения, таможенные пошлины, зона свободной торговли.

ЕАЭС сформирован на основе Таможенного союза России, Белоруссии и Казахстана и Единого экономического пространства. В пределах Союза обеспечивается свободный оборот товаров, капитала, рабочей силы. Страны-члены Союза проводят согласованную политику в главных сферах народного хозяйства.

ЕАЭС является международной организацией, направленной на развитие экономической интеграции между государствами-членами и обеспечение стабильного развития их национальных экономик. ЕАЭС открыт для вступления новых государств, разделяющих его цели и принципы, в соответствии с условиями, согласованными государствами-членами.

Экономическая интеграция - это эволюция экономического развития. «Открытый рынок это продукция более высокого качества, более низкая себестоимость, естественный спрос на новые технологии, развитие рыночной экономики. «Таможенный союз призван стимулировать торговлю. Члены блока не устанавливают импортные пошлины на товары друг друга, а товары, поступающие из-за пределов блока, облагаются налогом по тем же ставкам. Эти правила защищают участников от внешней конкуренции и поощряют торговлю внутри группы.

Несмотря на то, что основные экономические отношения союза в основном завязаны на отношении стран - участниц ЕАЭС, активно поощряются отношения союза с другими странами.
ЕАЭС имеет три основных институциональных формата для выстраивания взаимоотношений с внешними партнерами как показано на рис. 1.

В 2019 году между странами Евразийского экономического союза (ЕАЭС) и Китаем было подписано знаковое соглашение о торговоэкономическом сотрудничестве. Эта сделка снижает некоторые торговые барьеры и упрощает таможенные процедуры, создавая основу для более глубокой интеграции. Это выводит отношения между ЕАЭС и китайской инициативой «Пояс и путь» на новый уровень, предоставляя членам ЕАЭС возможность начать выстраивать партнерство с Китаем на относительно равных условиях.

Эта инициатива кардинально изменила экономику стран ЕАЭС. За последние семь лет Китай предоставил этим странам около 98 миллиардов долларов инвестиций для реализации 168 проектов.

В то же время отношения между Китаем как инвестором проекта и странами, где эти проекты реализуются, не всегда справедливы. С одной стороны, китайские деньги неизбежно стимулируют экономику этих стран. С другой стороны, эти страны могут стать слишком зависимыми от китайских инвестиций, как в случае с КазахстаHом.

За последние несколько лет роль китайского бизнеса возросла настолько, что под его кон-

\footnotetext{
* Статья подготовлена по результатам исследований, выполненных за счет средств по государственному заданию Финуниверситета
} 


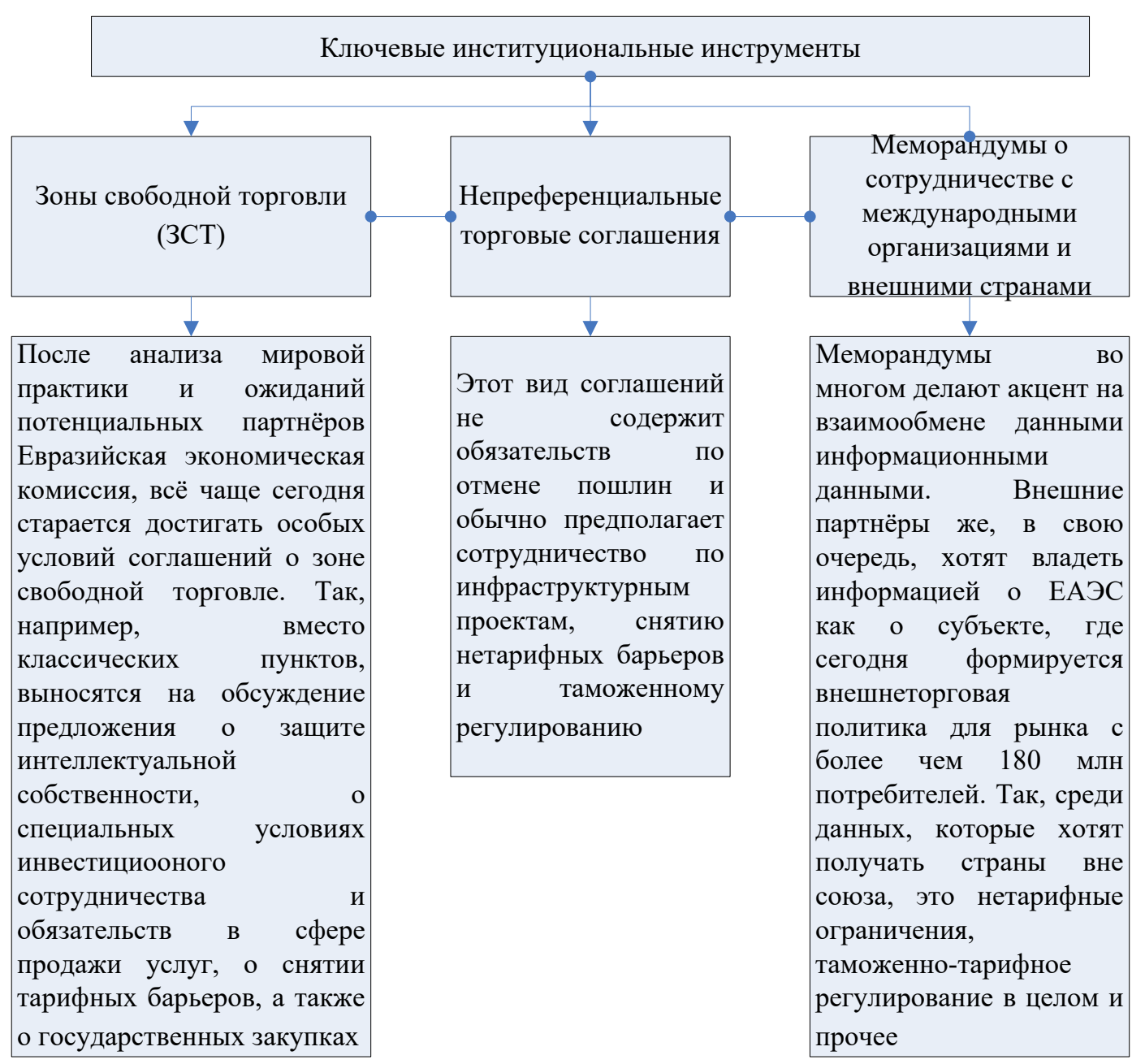

Рисунок 1. Ключевые институциональные инструменты ЕАЭС Источник: составлено авторами по материалам [1]

троль попали целые отрасли промышленности, особенно энергетический сектор.

Нефтегазовые проекты составляют 98\% инвестиций китайских транснациональных корпораций в Казахстан. В настоящее время около 20\% всей добычи нефти в стране связано с Китайской национальной нефтяной корпорацией, крупнейшей государственной энергетической компанией Китая.

В этих условиях особое значение приобретает соглашение о торгово-экономическом сотрудничестве. Это дает возможность членам ЕАЭС перейти к равноправному деловому торговому сотрудничеству с Китаем. ЕАЭС заинтересован в китайском рынке, и ему есть что предложить, прежде всего в природных ресурсах, которых в ЕАЭС в избытке.

Это особенно острый вопрос для России, по- скольку Европейский и американский рынки частично закрыты из-за санкций. Именно по этой причине страны-члены ЕАЭС соглашаются продавать Китаю природные ресурсы на выгодных условиях. В свою очередь, Китаю нужен партнер, способный обеспечить большие и стабильные поставки и относительно низкую цену.

Сельское хозяйство - это еще одна отрасль, которая имеет потенциал для построения взаимовыгодного партнерства. Россия стала крупнейшим экспортером пшеницы в Китай в 2017 году. Этому событию предшествовали интенсивные переговоры о способе транспортировки, которые заняли не один год. В Китае существовала потребность в том, чтобы зерно перевозилось в мешках, тогда как в России оно перевозится навалом. Переход от перевозки сыпучих грузов к выполнению китайского требования был эконо- 
мически невыгоден, поэтому Россия попросила его отменить.

Россия также стремится увеличить свой экспорт мяса в Китай. Российские сельхозкомпании, в том числе такие крупные животноводческие холдинги, как «Мираторг» и «Русагро», уже вложили в свои объекты на Дальнем Востоке около 1 миллиардов долларов.

В настоящее время из-за санитарных норм они работают в убыток, потому что не могут экспортировать свою продукцию в Китай. Переговоры о необходимых изменениях идут полным ходом, однако эти изменения вряд ли можно назвать быстрыми и простыми. Должно помочь и подписанное в Астане в мае 2018 года соглашение.

Китай обычно стремится вести переговоры с каждым партнером отдельно, потому что более мощная экономика неизбежно смещает уравнение власти в свою пользу. Таким образом, еще одной важной особенностью заключенного в Астане соглашения о торгово-экономическом сотрудничестве является то, что оно подписано между Китаем и всем ЕАЭС, а не только Россией, Беларусью или одной из центрально-азиатских стран в отдельности.

Наиболее оптимальная стратегия заключается в том, чтобы они действовали сообща, а не сотрудничали с Китаем на индивидуальной основе. Таким образом, страны-члены ЕАЭС имеют возможность выстраивать отношения с Китаем с точки зрения многостороннего партнерства и создания относительного баланса сил и интересов.

Конечно, ЕАЭС в его нынешнем состоянии явно не идеален. Страны-члены испытывают трудности в достижении консенсуса по различным вопросам. У них не всегда совпадают интересы. Чтобы найти баланс внутри Союза, требуются медленные и длительные переговоры, и этот процесс еще не вполне эффективен. Кроме того, органы ЕАЭС еще не начали полноценно функционировать. ЕАЭС-относительно молодая организация, поэтому, естественно, ему нужно время, чтобы выйти на полную мощность.

Россия - это центральная сила, стоящая за ЕАЭС. Она старается действовать постепенно, шаг за шагом выстраивая партнерские отношения. Москва осознала, что слишком сильное политическое и экономическое давление на постсоветские страны только оттолкнет ее соседей.

Именно поэтому делается акцент на выстра- ивании значимых точек соприкосновения и, самое главное, на понимании того, что ЕАЭС рано или поздно станет эффективным инструментом защиты общих экономических интересов.

У Китая больше возможностей для маневра, а странам-членам ЕАЭС отступать некуда. Для них Китай незаменим. Китай твердо намерен воплотить свою инициативу «Пояс и путь» в реальность, и у него есть альтернативные возможности. Если переговоры с ЕАЭС не увенчаются успехом, Китай обратится к Турции, Пакистану или другим ближневосточным странам, поскольку эти альтернативные страны также выиграют от реализации инициативы.

В конечном счете ЕАЭС и Китай должны работать над созданием зоны свободной торговли и, возможно, либерализацией движения капитала внутри этой зоны. Эти амбициозные цели не будут достигнуты в ближайшее время, но соглашение, подписанное в мае, представляет собой важный шаг вперед.

Помимо Китая у ЕАЭС налаживаются отношения с Узбекистаном. 80\% продукции Узбекистана проходит через страны - члены ЕАЭС: Казахстан, Кыргызстан и Россию. Кроме того, эти же страны являются конечными потребителями от 50\% до 80\% экспорта Узбекистана. Также интеграция означает улучшение условий для узбекских мигрантов в России и Казахстане.

Для Узбекистана подразумевается либо возможное полноправное членство, либо становление государством-наблюдателем. Тем не менее есть основания сделать вывод, что членство Узбекистана - это всего лишь вопрос времени.

Правительство страны, скорее всего, будет работать над поддержкой отраслей, которые будут негативно затронуты членством. В частности, Узбекистан будет в той или иной степени зависеть от России в сфере транспорта, транзита, производства, энергетики и подвергаться возможным осложнениям экономической и политической свободы.

Одним из ограничивающих аспектов станет запрет на закупку лекарств и медицинского оборудования из стран, не входящих в ЕАЭС, что, безусловно, приведет к росту цен. Узбекистан полагается на Украину, Германию и Израиль в отношении этих товаров, но будет ограничен более дорогими закупками из Казахстана и России.

Другой аспект - неконкурентоспособные кондитерские изделия и бытовая техника отечественных производителей, которые будут заме- 
нены более дешевыми, но более качественными продуктами, в первую очередь из Казахстана и России.

На настоящий момент у ЕАЭС подписано соглашение о свободной торговле с Сербией. Соглашение гармонизировало существующие двусторонние ССТ Сербии с Казахстаном, Россией и Беларусью. Он также создал аналогичный режим с Арменией и Кыргызстаном, которые не имели никаких преференций на сербском рынке.

Сербские товары также смогут выйти на рынок ЕАЭС с населением 183 млн. человек при более низких импортных пошлинах, а также на других благоприятных торговых условиях.

Помимо тарифных обязательств, соглашение обеспечивает наличие правовых новшеств, гарантирующих стабильность, предсказуемость и прозрачность торговых операций. Стороны дополнили нормативную часть соглашения последними правовыми новшествами.

Новые правовые новшества важны потому, что Сербия не является членом Всемирной торговой организации.

Помимо этого РФ настаивает на принятии Индии в ЕАЭС, что откроет значительные возможности партнерства третьих стран в Центрально-азиатско-Евразийском регионе.

Вьетнам обязался открыть рынок примерно для 90\% всех тарифных линий в рамках 10-летнего графика снижения тарифов. Отмена тарифа на продукцию, входящую в приоритетный перечень ЕАЭС, в том числе сельскохозяйственную продукцию (например, говядину, молочные продукты, пшеничную муку); через 3-5 лет после подписания соглашения - переработанное мясо и рыбу, электромашины, машины, используемые в сельском хозяйстве; через 5 лет - свинину, курицу; через 10 лет - алкогольные напит- ки и автомобили. Для некоторых специальных продуктов отмена тарифов будет происходить не ранее 2027 года для нефти, чугуна и стали.

ЕАЭС также должен был ликвидировать тарифную ставку в размере 59\% от общего числа тарифных линий. Группы товаров были исключены из импортной тарифной ставки: это сельскохозяйственная, лесная и рыбная продукция Вьетнама (большинство рыбопродуктов, некоторые отдельные виды свежих и переработанных овощей и фруктов, переработанное мясо и рыба, крупы, рис); и некоторые промышленные товары, в которых Вьетнам имеет преимущество в экспорте (текстиль и сырье текстильных материалов, обувь (особенно спортивная), машины, электронные компоненты, некоторые фармацевтические продукты, железо и сталь, резиновые изделия, а также дерево и мебель).

Вьетнам может продолжать расширять свою промышленную продуктовую линейку в будущем, тогда как страны ЕАЭС могут продолжать восстанавливать свое сельскохозяйственное производство, которое, за исключением тропических фруктов, вступает в конкуренцию с аналогичной Вьетнамской продукцией.

Картина взаимоотношений России и Вьетнама получается неоднозначной. В целом соглашение успешно реализуется в сфере торговли, но пока не развернуто в других сферах. В течение первых двух лет торговые последствия исчерпали себя, и возникли новые различия. Протекционистские механизмы препятствуют процессу либерализации и росту торговли.

Вышеизложенное свидетельствует, что торговые отношения ЕАЭС и стран, не входящих в союз, достаточно выгодны как для России, так и других стран-участниц ЕАЭС.

\section{Библиографический список}

1. V.D. Kovaleva, L.F. Suhova, Z. R. Kochkarova Eurasian Economic Intergation: Problems and Prospects // Academy of Strategic Management Journal.-2018. - № 17 Issue: 4.

2. Бурцева К.Ю. Анализ преимуществ интеграции для Ирана и ЕАЭС/ Экономические науки - М: 2020.№ 7(188). - С. 109-113.

3. Бурцева К.Ю., Зверинская А.А. Экономическая интеграция ЕАЭС со странами, не входящими в экономический союз / Вестник Самарского государственного университета путей сообщения.- Самара: Самарский гос. Ун-т путей сообщения, 2020.- Вып. 2 (48). - С.22-28.

4. Временное соглашение о ЗСТ ЕАЭС - Иран: вызовы и перспективы для евразийского бизнеса. URL: http:// eurasian-studies.org/archives/8772 Дата обращения: 20.04.2020 г. 